\title{
The View of International Law on The Pandemic Covid-19
}

\author{
Yapiter Marpi ${ }^{1}$, Erlangga $^{2}$ \\ \{yapitermarpi@gmail.com ${ }^{1}$, erlanggaakademisi@gmail.com ${ }^{2}$ \} \\ Department of Law Faculty Universitas Jakarta, Indonesia ${ }^{12}$
}

\begin{abstract}
The views of world countries on the handling of the Covid-19 Pandemic give the impression of solving the global health crisis. Whereas international law is a special mechanism in handling pandemics through the operationalization of International Health Regulations which are coordinated globally by the WHO international organization. The aim is to examine the implications of force on international law. The main approach to legal research method is to apply a total lockdown or physical distancing in accordance with the health protocol established by WHO. By elaborating, international law contains obligations, authorities, procedures, and roles and challenges faced in handling a global pandemic. Finding the fact that, IHR 2005 works on international law, but a 'one size fits all' instrument that can solve all the problems of handling the positive sum global health crisis to interdependence, institutionalism, multilateralism, and a zero-sum game democratic system where the state is strengthening.
\end{abstract}

Keywords: Pandemic; International Law; Privat Law; Countries

\section{Introduction}

The international world in 2020 will be shaken hard by the global pandemic crisis COVID-19. Especially the Indonesian State Government Ir. Jokowi and K.H Ma'ruf Amin who received the impact so that it could paralyze the joints of all sectors of growth. The health issue that was allegedly detected for the first time in the city of Wuhan, China in December 2019 was caused by a virus officially named SARS-COV-2. Instantly a great pandemic swept across the world. All countries in the world are busy with the spread of this deadly virus and there is no cure and vaccine yet. All the Leaders of the Nations are made frantic to overcome this virus, the world is not ready to face the massive spread of this virus. Every day there were mass casualties, overwhelming the hospital. Instantly the policies of many countries in the world changed.

The Head of State and his government are forced to take the policy as quickly as possible to stop the rate and spike and spread of this virus. Based on data released by the World Health Organization (WHO) as of April 20, it has spread to 170 countries and 34 territories in the world. WHO itself has established the current condition as a global pandemic with a very high-risk assessment? The number of positive cases caused by the Corona virus has reached $2,500,792$ with a total death toll of 175,694 globally. The most positive cases in major countries include the United States (900,926 cases), Spain (208,389 cases), Italy (187,327 cases), Germany (159,046 cases), England (133,499 cases), and France (117,961 cases). [1] Covid-19 not only affects public health which causes a large number of deaths, but also affects 
various sectors including the primary, secondary and tertiary sectors due to the cessation of social, cultural, religious, educational, business and so on. The impact of covid-19 has made a number of countries ask for compensation and accountability from China for the covid-19 pandemic. In the United States to be precise in the state of Florida, thousands of people signed a class action lawsuit.[2]

International Law has rules regarding state responsibility internationally that have been made by the United Nations (UN) which were adopted from the UN International Law Commission, namely the Responsibility of States for Internationally Wrongful Acts in 2001 (Draft Article ILC), Article 1 of these regulations regulates any international wrongdoing of a country which obliges the international responsibility of that country. The coronavirus causes a type of infectious disease called covid-19. Lock down is enforced in almost all countries in the world, namely by closing the doors in and out of the territory of a country. No person may freely enter and exit the territory of a State, be it a citizen of that country or a foreigner who will enter the territory of another State.[3]

Several unusual policies continue to be taken by a number of heads of state in the world, such as closing schools, houses of worship, tourist places but still this virus cannot be stopped from spreading, the State is forced to take even more extreme policies, namely closing its territories, or called lock down. State responsibility is closely related to a rule in which the fundamental principles of international law state that a country or party who has suffered losses has the right to receive compensation for the losses it has suffered. At the end of 2019, it was widely reported that a coronavirus had emerged from one of the Huanan Seafood Wholesale Markets in Hubei Province, Central China, to be precise in Wuhan City.[4]

In the economic field where the economic activities carried out by the community are limited, the OECD is in further concern for the impact on the political field where public trust is decreasing in its government, especially in terms of its ability to face this pandemic, or even spread to national security issues. From an international legal perspective, WHO holds the main mandate in public health affairs on a global scale. With the widespread local spread, the Wuhan health authorities reported this case to the Chinese National Health Commission, the Chinese Centre for Disease Control and Prevention (Chinese CDC), to notify the world health organization (WHO).

In January 2020, China's CDC successfully identified SARS-CoV-2, the newest type of coronavirus that causes fifteen of the fifty-nine cases of Wuhan pneumonia. This type of coronavirus was later identified as the cause of Covid-19. Such conditions require China to take mitigation measures. In less than one month since the identification of SARS-CoV-2, the Chinese government imposed a total quarantine (lockdown) in Wuhan City and fifteen other cities, eliminating the holidays for the Chinese New Year celebrations. These prevention efforts, however, are not strong enough to contain the spread of Covid-19 out of the country.

If anyone is sick and needs specialist treatment, they have to ask for official permission which could take several days. Then they have to pay a security escort to go to the hospital. In the midst of competition for global health resources, refugees are likely to be lost and neglected. In the past seven days, daily Covid-19 cases in India touched an average of over 73,000 per day. The rate of infection is faster than reported cases in other countries in the world. The largest contributor to new cases in India is Maharasthra State, with the capital Mumbai accounting for more than 55 percent of new Covid-19 cases in the past two weeks. Experts argue that the spike in new Covid-19 cases is now the result of ignoring health protocols in public places, such as wearing masks and maintaining social distancing and preventing crowds. 
In the capital New Delhi, the chief minister ruled out lockdown options despite the surge in new Covid-19 cases. Local police say they are imposing more sanctions on people who do not wear masks. Prime Minister Narendra Modi tends to avoid reintroducing lockdowns, such as March 2020, which cause economic hardship for its residents.[5] Even with aid and medical supplies donated to several countries, it is unclear how much will flow to the refugees. British non-profit organization Oxfam described the situation in a camp in Rakhine state that is struggling to get health care even in its current state. IOM said if there are cases of the COVID-19 virus among refugees, it could remain undetected and thus pose a risk to migrants living with them and local residents.[6]

As the status of the health crisis [7] has increased to become a public health emergency of international concern (PHEIC), the epicentre of the spread of Covid-19 has shifted to Lombardy, Italy, which has formed a new cluster in the European region. As of March 2020, the transmission rate in the European region has reached 4,505 cases and 113 deaths. As of the end of January, new cases emerged outside of China such as: Thailand, Japan and South Korea in the Asian region, as well as France and Germany in the European region, each of which had a distribution cluster which, when traced, had a history of traveling from and towards China.

In this case, the delay in early detection of the spread clusters further complicates the process of isolating local cases that are scattered throughout the European region. The escalation in the spread of cases and the percentage of the death rate due to Covid-19 - a total of up to 110,000 cases spread across 110 countries with a death rate of 3.9 percent globally, finally prompted WHO to declare the condition a pandemic at the end of March. The status of this global pandemic, "forces" countries in the world to take drastic steps in order to reduce the rate of spread of Covid-19.

As a result of the lock down that has been established in a number of countries, of course it has a profound impact on these international refugees. This policy certainly has an impact on many people, not only for citizens but also for foreigners who want to enter the territory of the country, including international refugees who are currently residing in a country to get protection or who will seek refuge in a new country. As in the handling of the previous pandemic, WHO returned to operationalizing the 2005 International Health Regulation (IHR) framework in handling the Covid-19 pandemic.

Entering the new decade, the world's attention is focused on Wuhan, the capital of Hubei province, People's Republic of China. Since the end of 2019, Wuhan has reported a series of deaths caused by diseases with pneumonia-like characteristics (pneumonia-like illness).[8] Apart from being a health problem, the application of physical distancing in facing this crisis also has implications for other fields. However, the stuttering of even developed countries raises questions about the mechanism of the framework used to solve the global health crisis. Based on this description, producing a problem formulation from this article is how the method of solving the handling of the Covid-19 pandemic in international law?

However, some of them have to fend for themselves to survive and protect themselves from the contagious COVID-19 disease. The United Nations (UN) estimates that more than 6.6 million people live in camps around the world. They make up the bulk of the global refugee population, which is estimated at around 26 million, and there are about two million people living in self-made camps that are usually made from very simple local materials. They are also live-in dense communities and do not have access to social and economic assistance.[9] To be able to answer the formulation of the problem, the discussion in this article will be divided into three parts: the first part will describe the handling of the pandemic situation in international law with special attention to the international organization WHO. 
In the second part, this article seeks to elaborate on the obligations, authorities, procedures, and roles and challenges faced in handling previous pandemics. Finally, the third part of the discussion of this article is the responsibility of the country of origin of the outbreak for the Covid-19 pandemic that has spread globally to handle the Covid-19 pandemic. Many analyses have emerged related to the occurrence of the Covid-19 pandemic, starting from a review of the health sector, that types of infectious diseases which attacks the human respiratory system is not a new disease, but comes from a mutated corona virus and is making its character increasingly malignant with rapid transmission, especially when it comes to humans who already have congenital disease. However, it is more important to note that the disease pandemic issue also has an impact on the international political constellation

\section{Research Methods and Assessment}

This type of research uses the Normative research type. Normative research is research that examines various literatures and statutory provisions that are closely related to the problem to be studied. The approach used in this research is:[10]

a. Legislative Approach, which is an approach that examines the laws and regulations that are relevant to the issues discussed

b. Conceptual Approach, which is an approach that examines the concepts / concepts or views of experts related to the issues discussed in this study. The technique of collecting legal materials in this research was obtained through library research either through searches.

\subsection{State Responsibility in International Law Due to Pandemic Outbreaks}

Indonesia's position, which is considered ambiguous, has actually caused a domestic polemic within the country. Indonesia's open attitude towards cooperation with many countries, including the intensity of its close cooperation with China, has drawn criticism from various groups, both domestic and international.[11] The criticism that is often given is that the bilateral relationship between China and Indonesia is considered unbalanced. The term state responsibility is still developing to find an established and solid concept because until now it has not been explicitly stated about the term responsibility.

As a result, the discussion of it today is still very confusing. Likewise, regarding the provisions of international law governing state responsibility, until now there has been no established provision. In general, what can be stated by international legal experts is only at the stage of setting out the conditions or characteristics of a state's responsibility in analysing state responsibility.

However, many international legal experts acknowledge that state responsibility is a fundamental principle of international law. International law classifies rules into two types, namely:[12]

a. Primary rules are a set of rules that describe the rights and obligations of the state which are stated in the form of treaties, customary law or other instruments.

b. Secondary rules are a set of rules that describe how and what are the legal consequences if a country violates primary rules. These secondary rules are the law of state responsibility.

Restitution in Article 35 of the ILC Draft Articles is defined as an act to restore the condition to the way it was before or before the violation occurred as long as it is materially 
not impossible to do or as long as it is deemed not a disproportionate burden. Meanwhile, compensation is the responsibility of the state in the form of payment of compensation for losses caused by an act which is said to be wrong according to international law as long as it does not involve things that have been done properly through restitution. As with restitution and compensation, fulfilment is made as long as the restitution or compensation does not work well or is not satisfactory.

Fulfilment can be in the form of acknowledgment of violation, statement of regret or formal apology or other means deemed appropriate. Covid-19 is a contagious disease caused by a newly discovered type of coronavirus. This virus causes infections of the respiratory tract in humans ranging from cold coughs to Middle East Respiratory Syndrome (MERS) and severe acute respiratory syndrome (SARS). There is a hypothesis that suggests that SARS$\mathrm{CoV}-2$ originated from mutated bats that then infected humans. Pangolins are suspected to be an intermediate reservoir in the Covid 19 case. The main source of transmission of SARSCoV-2 is human-to-human which causes its spread to become more aggressive. Transmission is generally due to close contact with Covid-19 patients, besides that through droplets that come out when coughing or sneezing can cause transmission. Viruses can also be detected in inanimate objects such as door handles, toilet seats, light switches, windows, cabinets to vents, but not in air samples.[13]

The interpretation of state responsibility can be interpreted as an obligation to make improvements that arise as a result of a country failing to comply with legal obligations based on international law, whereas according to the Black's Law Dictionary there is only a narrow definition of responsibility, namely answerability or accountability. State responsibility is a fundamental principle in international law which originates from the doctrine of international jurists, if there is a violation of an international obligation either based on international treaties or based on international customs, the state will be responsible. The principle of equality and state sovereignty in international law also creates state responsibility which then gives authority to a country whose rights are violated to demand a right in the form of reparation. Even though a country has sovereignty over its country, it does not allow that country to use its sovereignty without respecting the sovereignty of other countries. International law has stipulated that this sovereignty is related to the obligation not to abuse the sovereignty itself. Therefore, if there is an abuse of such sovereignty, a country can be held accountable for its actions or negligence.[14]

Meanwhile, in the business world, the global travel industry, from airlines to shipping companies, casinos to hotels, experienced a decrease in activity of more than 90 percent. In the tertiary sector, the education system around the world, most governments have temporarily closed educational institutions in an effort to close access to the spread of this pandemic. Thus, to reduce the impact of direct closure, UNESCO recommends that the learning process be carried out online by opening a platform. However, in Indonesia, online learning has several obstacles, including limited mastery of information technology for both teachers and students, inadequate facilities and infrastructure, limited internet access, and inadequate budgets. The world condition amidst the COVID-19 pandemic presents a challenge for many developing countries that must build their health resilience amidst the slowing of their economies, both in the field of health services or medical infrastructure.[15]

The global political constellation will undergo many changes as an implication of the COVID-19 pandemic, starting from the mapping of the power of countries and their alliances, to the direction of foreign policy of many countries. In Articles 1 and 2 of the ILC Draft Articles, if the actions of a country can be attributed to the state and the actions of that state have violated international obligations, the actions of that state can be blamed according to 
international law.18 However, regarding the limits when a country is said to have violated international law is not contained in ILC Draft Articles. Thus, in practice this is determined through the application of the sources of primary international law (provisions of international treaties, customary international law and other sources of international law).

a. Actions attributable to a country In general, the applicable provisions in this case are that only the actions of state organs, the government and / or their officials (persons or entities acting on the basis of orders / directions, advice, or supervision of these organs) that is attributable to the country. These organs include national, regional and local government organs, and people and entities at any level, or any person or entity. which has a status as an organ of government based on the national law of a country. In addition, it includes people who actually act as organs of government even though they are not categorized as such by the national law of the country concerned.

b. Violation of an international obligation An act attributable to a country is not sufficient to create state responsibility, that act must be proven as an act that violates an international obligation. In order to determine whether or not an international obligation is violated, it must be determined on a case-by-case basis.

However, regarding an act that occurred before the country was bound by an international obligation, the act of a country was not considered a violation of an international obligation. The COVID 19 pandemic would cause a shift in global power that was previously considered the United States and Europe as the main axis of the west, now slowly shifted to the eastern axis, namely Singapore and South Korea, including China in it. The western axis is considered to have failed in providing an effective response when the COVID 19 pandemic occurred, on the other hand China, which was considered to have made a mistake that caused this pandemic, began to show a better response, even China played a significant role in collaborating in the procurement of medical devices in many countries. Cooperation in the field of health research is also being carried out intensively by China.

\subsection{Due to the negligence of the spread of the pandemic outbreak in international law}

The COVID 19 pandemic provides an illustration of the importance of infiltrating health issues into foreign policy, as discussed in the previous section. Given the health implications for vital sectors of the country, such as the economy to defence. When health issues have been included in foreign policy priorities, the state has readiness related to disaster mitigation of an outbreak or a pandemic when it occurs.[16] Apart from the problems related to the relationship between Indonesia and China, referring to the principle of free and active foreign policy, so that the relationship is considered not denying Indonesia's impartiality in establishing diplomatic relations with any party.

Including during the COVID 19 pandemic, Indonesia is again intensively cooperating with China in vaccine trial research activities which will be launched in early 2021. It is clear that Article 6 of the IHR (International Health Regulation) of 2005 states that "Every participating country must assess the events that occur in the region using the decision instrument in Annex-2. Each participating country must notify WHO, by the most efficient means of communication available, through IHR National Focal-Points and within 24 hours of an assessment of public health information of all incidents that lead to PHEIC in its territory according to the health decision-making instruments and measures used. in response to the incident.

If the notification received by WHO will involve the competence of the International Atomic Energy Agency (IAEA), WHO must immediately notify the IAEA. " So, a country must notify WHO within 24 hours if a PHEIC is suspected. Furthermore, Article 7 of the IHR 
requires countries to notify WHO "all relevant public health information" during the occurrence of the PHEIC. This, as the parties accuse, means that China is late in reporting to WHO because it does not report within 24 hours, however, the party who is complaining is obliged to prove what is accused of China.

However, obtaining this evidence is not easy because the Chinese government does not easily provide access for anyone. Criticism has also been sent to the Chinese government for being considered late in reporting to WHO and covering up the outbreak, 38 included actions by the Wuhan authorities on a doctor who warned his colleagues about the new SARS virus, the authorities alleged that Li Wenliang had spread fake news and disturbed social order. The high level of spread has made almost all countries create lockdown policies or closure of areas from migration to overcome this spread.

The lockdown policies implemented by several countries have resulted in diverted work at home, restrictions on traveling and gathering, and in Europe people are not allowed to use public transportation and efforts are made to avoid public spaces. Covid-19 not only affects public health which causes many deaths, but also affects various sectors including the primary, secondary and tertiary sectors due to the cessation of social, cultural, religious, educational, business and so on.

In the primary sector, which includes agriculture and petroleum, agricultural commodity prices fell by 20 percent due to a lack of demand from the secondary sector, the manufacturing industry experienced problems with imports and labor that made it impossible to work from home due to disruptions to the supply chain and self-isolation policies. Although a lesson related to Chinese aid or investment must be examined carefully, it happened when Italy returned a number of medical devices to China because they did not meet international standards. Therefore, the European Union demands China to provide compensation for negligence that has been made, thus causing the world to experience the Covid 19 pandemic.[17]

\subsection{Forms of Responsibilities and Obligations of International Law Due to countries spreading the covid-19 pandemic}

There is an international legal obligation that applies between two certain countries. International Health Regulations (IHR) are international legal instruments that are legally binding on 196 countries, including 194 that are WHO member countries. In the case of Covid-19, China and several countries that have asked for responsibility, such as the United States and Israel, are legally bound by the IHR and are member countries of the WHO. IHR emerged as a response to the deadly epidemic that has hit Europe.

The IHR creates rights and obligations for states including requirements to report public health-related incidents. In addition, it includes outlining the criteria for determining whether a particular event is a "troubling public health emergency" or not. According to I Dewa Palguna, the characteristic of a damage or loss in its development is no longer considered a characteristic that must exist in every case regarding the birth of state responsibility.[18]

This can be seen from the existence of an act that is blamed according to international law even though no other party or other country is harmed, such as in cases of violations of human rights in Article 24 of the European Convention on Human Rights. In addition, in Article 3 of the ILC Draft Articles in every definition of an act that is blamed according to international law, it eliminates the condition for damages. Public health emergency of international concern (public health emergency, abbreviated as PHEIC) is an extraordinary event provided that the spread of disease internationally can pose a risk to public health in other countries and potentially require an international coordinated response[19]. 
There is no provision regarding compensation in the IHR (International Health Regulation) for the delay or negligence of such notification, but in Article 75 of the WHO Constitution it is explained that "Any questions and disputes that are not resolved through negotiations or by the Health Assembly will be referred to the International Court of Justice, unless the parties-related parties agree to other settlement methods. This article can be a way for countries that sue China to the International Court, namely the International Court of Justice, to be held accountable for Covid-19.

However, it requires Chinese approval or China must declare acceptance "in writing" and in this case, China is a permanent member of the UN Security Council which has veto power. In the case of the ICC (International Criminal Court), China is not a member of the Rome Statute, it is impossible for China to agree to the jurisdiction of the ICC in this case and it must be proven that China's actions are crimes that fall under the jurisdiction of the international tribunal, namely crimes related to the crime of genocide, crime against humanity, war crimes and crimes of aggression as stipulated in Article 5 of the Rome Statute. In addition, China is protected by the principle of par in parem non habet imperium and immunity to sovereignty, that is, parties (countries) of equal position do not have jurisdiction over other parties (equals do not have jurisdiction over each other).[20]

According to Hans Kelsen, the adage principle "Par in parem non habet imperium", has several meanings. First, a country cannot exercise jurisdiction through its courts over the actions of another state, unless that state allows it. Second, a court established under an international treaty cannot adjudicate the actions of a country that is not a member or participant of that international treaty. Third, the courts of a country have no right to question the legality of an act of another country which is carried out in its territory. The WHO constitution provides for the main decision-making procedures within the organization, which have quite broad powers when compared to other international organizations.

As stated in Articles 21 and 22, it is stated:

Article 21

The Health Assembly shall have authority to adopt regulations concerning:

a. sanitary and quarantine requirements and other procedures designed to prevent the international spread of disease;

b. nomenclatures with respect to diseases, causes of death and public health practices;

c. standards with respect to diagnostic procedures for international use;

d. standards with respect to the safety, purity and potency of biological, pharmaceutical and similar products moving in international commerce;

e. advertising and labelling of biological, pharmaceutical and similar products moving in international commerce.

Article 22

Regulations adopted pursuant to Article 21 shall come into force for all Members after due notice has been given of their adoption by the Health Assembly except for such Members as may notify the Director-General of rejection or reservations within the period stated in the notice.

This condition changed drastically when countries in the world were hit by the COVID19 pandemic crisis at the end of which was officially declared by WHO on March 11, 2020. The state revised its previously limited role to be more aggressive. The state strengthens itself, and shows a coercive attitude towards its people with the aim of breaking the chain of spreading the virus. The state imposes restrictions on its people, both in terms of calling for physical distancing, closing activities that make people gather, such as teaching and learning activities at schools and universities, even implementing quarantine areas that become the 
epicentre of the spread, or even carrying out a total lockdown on the country or prohibiting entry to migrants from areas that have high cases of the spread of the virus[21].

On August 4, 2020, President Joko Widodo issued a Presidential Instruction regarding the Implementation of the Covid-19 Health Protocol. This policy is outlined in Presidential Instruction Number 6 of 2020 concerning Increasing Discipline and Law Enforcement of Health Protocols in the Prevention and Control of Corona Virus Disease 2019, which is necessary for the prevention and control of Covid-19. This Presidential Instruction is intended for all Provinces, Regencies / Cities and all regions of Indonesia. In Indonesia, a law is a substance which is a regulation made by the government that must be obeyed by all people, officials, and the government itself. However, for increased discipline in the prevention and control of Covid-19, there is no law that specifically regulates discipline in the prevention and control of Covid-19.

So, the issuance of Presidential Instruction Number 6 of 2020 concerning Increasing Discipline and Law Enforcement of Health Protocols in the Prevention and Control of Corona Virus Disease 2019. Especially with the world currently experiencing polarization of political power, that is what stimulates the intensity of the south-south alliance to become stronger, where there is Brazil. and South Africa, as well as an alliance of countries based on the same ideology, such as China, Cuba, Russia. The south-south forum is considered capable of voicing the interests of developing countries in a more proportionate manner, compared to the north-south forum.

\section{Conclusion}

The emergence of the spread of the Covid-19 pandemic outbreak is an act or negligence that violates these international legal obligations so that the existence of state responsibility is still questionable. The basis used is that China is considered to be not transparent and it is late in reporting to WHO, the complainant is obliged to prove what China is accused of. However, obtaining this evidence is not easy because the Chinese government does not easily provide access for anyone. The conclusion is very clear that it is not easy for China to be held responsible for the Covid-19 case. This needs to be supported by strong and convincing legal facts.

In addition, it is difficult to bring this Covid-19 case to international court because China is not a member of the Rome Statute and is protected by the principle of par in parem non habet imperial and immunity to sovereignty. If the parties can prove that China in the Covid19 case has fulfilled the three characteristics of the existence of responsibility, according to Article 34 of the ILC Draft Articles, China is responsible for making improvements which can be in the form of restitution, compensation, and fulfilment.

This condition then led to a polemic to control the rate of spread of infectious diseases: the low rate of reporting of the spread of disease became a common practice and as a result WHO did not have the means of law enforcement. Every country has the exclusive right to use its territory and fully implement its national law, but the state has the obligation to ensure that all activities or actions carried out in its national territory do not result in damage or loss to the territory of other countries. So, a country has an obligation not to abuse its sovereignty. 


\section{Acknowledgements}

The author's message to WHO is to be able to take firm action against law enforcement. For the countries that spread the covid pandemic outbreak, so that they can be held accountable in international law to be obeyed and addressed wisely. To the State of Indonesia to be able to ask for moral and material compensation due to the Covid-19 pandemic outbreak. Appeals to all domestic nations and nations in ASEAN and throughout Europe, both to adhere to the Anglo-Saxon law and civil law so that they can uphold the spirit of justice and legal accountability consciously and wisely.

\section{References}

[1] W. H. O. (WHO), "Coronavirus Deaseas 2019 (COVID-19) Situation Report-94,” who, 2021. https://www.who.int/docs/default (accessed Mar. 24, 2021).

[2] S. Nadilla, "Krisis Covid-19: Perspektif Hukum Internasional Terhadap Pandemi," Maj. Huk. Nas., vol. 50, no. 2, pp. 261-280, 2020, doi: DOI: https://doi.org/10.33331/mhn.v50i2.65.

[3] R. Nadia Apriliyawati, Melly Aida, "Tanggung Jawab Negara Asal Wabah Terhadap Pandemi Menurut Hukum Internasional (Studi Kasus Pandemi Covid-19)," J. Log., vol. 12, no. 01, pp. 4739-4727, 2021, doi: DOI: https://doi.org/10.25134/logika.v12i01.3756.

[4] H. C. Black, A Dictionary of Law. New York: Oxford University Press, 2002.

[5] A. Ramadhan, "Abai Protokol Kesehatan, India Laporkan Kasus Covid-19 Tertinggi Sejak Pandemi," kompas, 2021. https://www.kompas.id/baca/internasional/2021/04/05/abai-protokolkesehatan-india-laporkan-kasus-covid-19-tertinggi-sejak-pandemi/?_t=\# (accessed Apr. 05, 2021).

[6] B. A. Garner, Black's Law Dictionary. New York: Claitors Pub Division, 2005.

[7] E. Marpi, Yapiter, "The Criticism of Social Justice in Economic Gap," Insign. J. Int. Relations, vol. 2, no. 10, pp. 23-31, 2021, doi: https://doi.org/10.20884/1.ins.2021.0.0.3759.

[8] B. T. E. and K. N. Yapiter Marpi, Erlangga, "Legal Effective of Putting 'Business as Usual' Clause in Agreements," Int. J. Criminol. Sociol., vol. 10, no. Law, pp. 58-70, 2021, doi: /10.6000/19294409.2021.10.09.

[9] Y. Marpi, Ilmu hukum suatu pengantar. Tasikmalaya: PT. Zona Media Mandiri, 2021.

[10] A. Lebret, "COVID-19 pandemic and derogation to human rights," J. Law Biosci., vol. 7, no. 1, pp. 1-15, 2020, doi: https://doi.org/10.1093/jlb/lsaa015.

[11] A. Sujatmoko, Tanggung Jawab Negara Atas Pelanggaran Berat HAM: Indonesia. Jakarta: Grasindo, 2005.

[12] H. Adolf, Aspek-Aspek Negara Dalam Hukum Internasional. Jakarta: Rajawali Pers, 1991.

[13] R. C. Hingorani, Modern International Law. New York: Oceana Publication, 1984.

[14] D. R. Singer, "Health policy and technology challenges in responding to the COVID-19 pandemic," Natl. Cent. Biotechnol. Inf. J., vol. 9, no. 2, pp. 123-125, 2020, doi: 10.1016/j.hlpt.2020.04.011.

[15] I. QC, "COVID-19: Fear, quackery, false representations and the law," Int. J. Law Psychiatry, vol. 72, no. 1, p. 123, 2020, doi: https://doi.org/10.1016/j.ijlp.2020.101611.

[16] Y. Marpi, Perlindungan hukum terhadap konsumen atas keabsahan kontrak elektronik dalam transaksi e-commerce. Tasikmalaya: Pt. Zona Media Mandiri, 2020.

[17] B. M. M. Lawrence O. Gostin, Roojin Habibi, "Has Global Health Law Risen to Meet the COVID19 Challenge? Revisiting the International Health Regulations to Prepare for Future Threats," $J$. Law, Med. Ethics, vol. 2, no. 2, p. 110, 2020, doi: https://doi.org/10.1177/1073110520935354.

[18] W. A. Kerr, "The COVID-19 pandemic and agriculture: Short- and long-run implications for international trade relations," Can. J. Agric. Econ., vol. 10, no. 1, 2020, doi: https://doi.org/10.1111/cjag.12230Citations.

[19] L. GRUSZCZYNSKI, "The COVID-19 Pandemic and International Trade: Temporary Turbulence or Paradigm Shift?," Eur. J. Risk Regul., vol. 11, no. 2, pp. 337-342, 2020, doi: DOI: https://doi.org/10.1017/err.2020.29.

[20] B. D.Kelly, "Emergency mental health legislation in response to the Covid-19 (Coronavirus) 
pandemic in Ireland: Urgency, necessity and proportionality," Int. J. Law Psychiatry, vol. 5, no. 2, 2020, doi: https://doi.org/10.1016/j.ijlp.2020.101564.

[21] B. D. K. W Cullen, G Gulati, "Mental health in the COVID-19 pandemic," QJM An Int. J. Med., vol. 113, no. 5, pp. 311-312, 2020, doi: https://doi.org/10.1093/qjmed/hcaa110 